\title{
Notes on the vocalizations of Tawny-crowned Greenlet (Hylophilus ochraceiceps)
}

Peter Boesman

In the following we briefly analyze and compare voice of the different races of Tawnycrowned Greenlet (Hylophilus ochraceiceps). We also try to quantify the extent of any vocal differences using the criteria proposed by Tobias et al. (2010), as a support for taxonomic review. We have made use of sound recordings available on-line from Xeno Canto (XC) and Macaulay Library (ML).

We have compared the following 3 groups:

North West (H. o. ochraceiceps, H. o. pallidipectus, H. o. pacificus, H. o. nelsoni, H. o. bulunensis)

Song is a repeated drawn-out whistle, rather flat in pitch or slightly ascending. $(n=6)$

$\begin{array}{llll} & & \text { Average } & \mathrm{SD} \\ \text { min. freq. } & 2900-3500 \mathrm{~Hz} & 3275 \mathrm{~Hz} & 193 \mathrm{~Hz} \\ \text { max. freq. } & 3250-3850 \mathrm{~Hz} & 3658 \mathrm{~Hz} & 198 \mathrm{~Hz} \\ \text { total length } & 0.55-0.73 \mathrm{~s} & 0.64 \mathrm{~s} & 0.05 \mathrm{~s} \\ \text { freq. range } & 300-500 \mathrm{~Hz} & 383 \mathrm{~Hz} & 69 \mathrm{~Hz} \\ \text { \# notes } & 1 & 1 & 0\end{array}$

Amazon (H. o. ferrugineifrons, H. o. viridior, H. o. lutescens, H. o. rubrifrons) Song is a repeated drawn-out whistle, rather flat in pitch, slightly ascending or descending. $(n=9)$

$\begin{array}{llll} & & \text { Average } & \text { SD } \\ \text { min. freq. } & 2550-3200 \mathrm{~Hz} & 2707 \mathrm{~Hz} & 191 \mathrm{~Hz} \\ \text { max. freq. } & 3000-4100 \mathrm{~Hz} & 3202 \mathrm{~Hz} & 346 \mathrm{~Hz} \\ \text { total length } & 0.66-0.98 \mathrm{~s} & 0.76 \mathrm{~s} & 0.10 \mathrm{~s} \\ \text { freq. range } & 220-900 \mathrm{~Hz} & 495 \mathrm{~Hz} & 174 \mathrm{~Hz} \\ \text { \# notes } & 1 & 1 & 0\end{array}$

Guianas (H. o. luteifrons)

Song is a repeated phrase of two slightly descending whistles, the second one lower-pitched and longer than the first one $(n=8)$

$\begin{array}{llll} & & \text { Average } & \mathrm{SD} \\ \text { min. freq. } & 2750-3040 \mathrm{~Hz} & 2942 \mathrm{~Hz} & 87 \mathrm{~Hz} \\ \text { max. freq. } & 3600-4700 \mathrm{~Hz} & 4002 \mathrm{~Hz} & 343 \mathrm{~Hz} \\ \text { total length } & 1.10-1.56 \mathrm{~s} & 1.28 \mathrm{~s} & 0.16 \mathrm{~s} \\ \text { freq. range } & 560-1800 \mathrm{~Hz} & 1060 \mathrm{~Hz} & 350 \mathrm{~Hz} \\ \text { \# notes } & 2 & 2 & 0\end{array}$



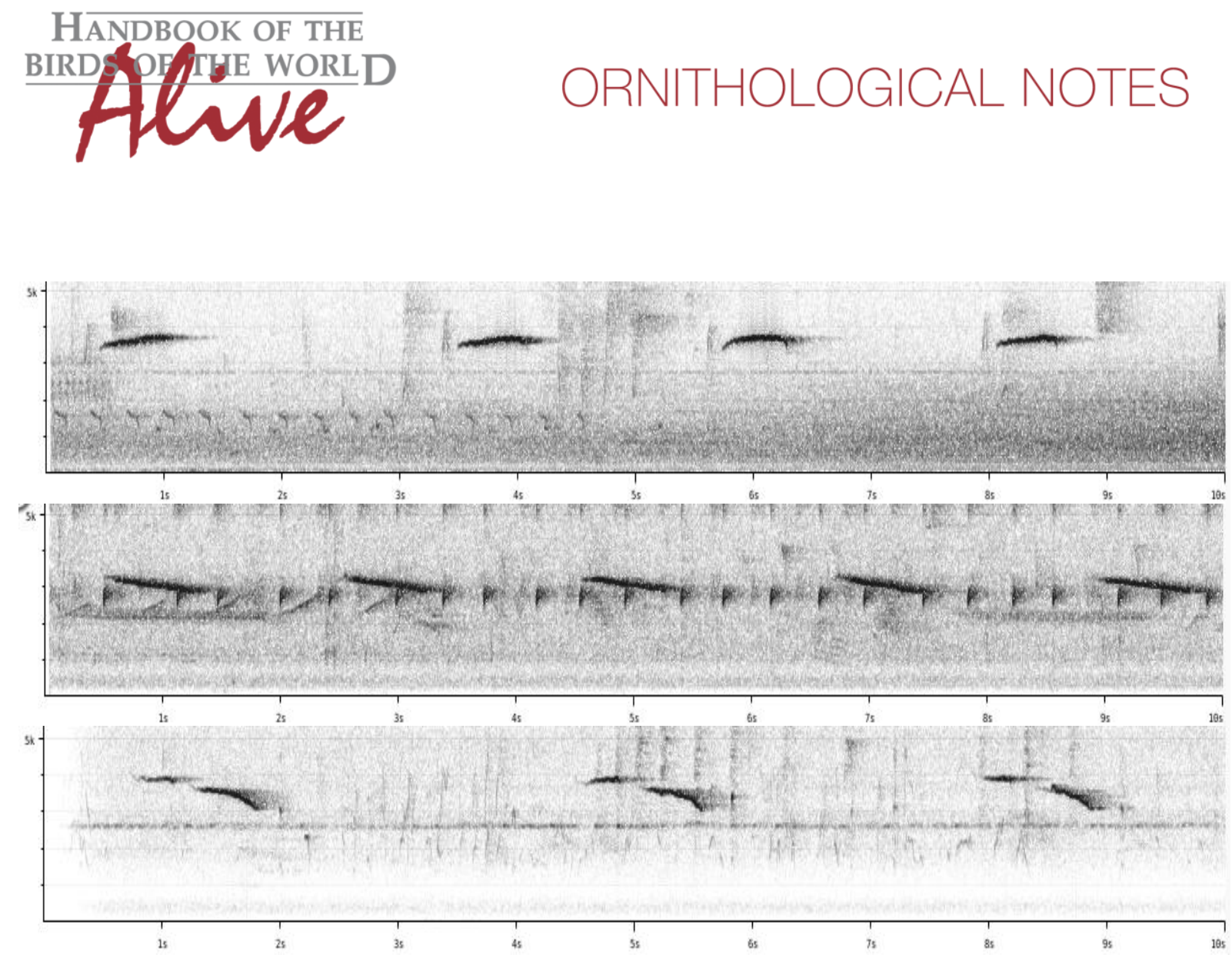

Figure 1: top to bottom: typical song of North West group, Amazon group and Guianas group

Surprisingly, the different song of luteifrons has seemingly nowhere been picked up in literature: its song consists of two notes with decreasing pitch (score 4), resulting in an overall longer song phrase (score 2-3) and larger frequency range (score 1-2).

When applying Tobias criteria, this would lead to a total vocal score of about 5 vs. all other races.

Birds of North West and Amazon differ slightly, NW birds having on average a higher-pitched voice (score 1-2) and slightly shorter whistles (score 1). Total score 2-3.

The exact geographical boundaries between ferrugineifrons and luteifrons will need more study, to find out whether the two taxa co-exist or not. Interestingly, based on voice birds of E Venezuela are luteifrons (Guianan group) while birds of SE Venezuela are ferrugineifrons (Amazonian group), a pattern also seen in some other species. North of Manaus, most birds are luteifrons, but one recording is not (if correctly identified, it is a background voice on XC286603, and might equally be song of Collared Gnatwren Microbates collaris).

A single recording of presumed race lutescens (XC120183) apparently consists of a 2-note song, but else lacks resemblance with luteifrons. rubrifrons at the other hand sings 'normal' song. To be further investigated.

All in all, we can conclude that the Guianan group clearly stands apart vocally. 
This note was finalized on 22nd October 2015, using sound recordings available on-line at that moment. We would like to thank in particular the many sound recordists who placed their recordings for this species on $\mathrm{XC}$ and $\mathrm{ML}$.

\section{References}

Tobias, J.A., Seddon, N., Spottiswoode, C.N., Pilgrim, J.D., Fishpool, L.D.C. \& Collar, N.J. (2010). Quantitative criteria for species delimitation. Ibis 152(4): 724-746.

\section{Recommended citation}

Boesman, P. (2016). Notes on the vocalizations of Tawny-crowned Greenlet (Hylophilus ochraceiceps). HBW Alive Ornithological Note 168. In: Handbook of the Birds of the World Alive. Lynx Edicions, Barcelona. (retrieved from http://www.hbw.com/node/932098 on 19 August 2016). 